\title{
Composition and spatiotemporal distribution of benthic macrofauna in a macrotidal estuary on the Amazonian Coast of the State of Maranhão, Brazil
}

\author{
Helen Roberta Silva Ferreira ${ }^{*}{ }^{\oplus}$, Antonio Carlos Leal de Castro², Marco \\ Valério Jansen Cutrim', Verônica Maria de Oliveira ${ }^{3}$ \\ 1 Universidade Federal do Maranhão, Programa de Pós-Graduação em Oceanografia \\ (Cidade Universitária Dom Delgado, Av. dos Portugueses, 1966, Bacanga - CEP 65080-805, São Luís - Maranhão - Brazil) \\ 2 Universidade Federal do Maranhão, Programa de Pós-Graduação em Desenvolvimento e Meio Ambiente \\ (Cidade Universitária Dom Delgado, Av. dos Portugueses, 1966, Bacanga - CEP 65080-805, São Luís - Maranhão - Brazil) \\ ${ }^{3}$ Universidade Estadual do Maranhão, Programa de Pós-Graduação em Recursos Aquáticos e Pesca \\ (Cidade Universitária Paulo VI, Av. Lourenço Vieira da Silva, n 1000, Jardim São Cristovão, CEP 65055-310 - São Luís - Maranhão - Brazil)
}

*Corresponding author: nelehroberta@hotmail.com

\section{AbStRACt}

The aim of the present study was to analyse the composition and spatiotemporal distribution of the benthic macrofauna in the estuary of the Perizes River (state of Maranhão, Brazil). Biological and environmental samples were collected at five sampling sites along the estuary during six campaigns covering the months of September, October and November 2016 (dry period) and February, March and April 2017 (wet period). Sampling was performed with a van Veen grab sampler $(682 \mathrm{~cm} 2)$. Environmental variables as temperature, $\mathrm{pH}$, salinity, dissolved oxygen, saturation and water transparency were measured and related to the biological data at each sampling site. After collection the samples were sieved through a $0.5 \mathrm{~mm}$ mesh and the organisms fixed in a 10\% formaline solution. A total of 35,597 individuals belonging to 84 taxa were identified, corresponding to Insecta, Mollusca, Crustacea, Annelida, Nematoda, Nemertea, Sipuncula and Collembola. Polychaeta showed the greatest species richness, while Tanaidacea were the most abundant. No gradient was found throughout the sampling sites with regard to the environmental variables, but marked differences were found in the temporal distribution. The temporal distribution of the benthic macrofauna was influenced by salinity and rainfall. Oligochaeta and Tanaidacea were abundant at all sampling sites. Acari were abundant in the inner portion of the estuary, while the number of Ostracoda was very high in the outer portion. The structure of the macrobenthic community differed in composition from the majority of the studies on estuaries, with the dominance of Tanaidacea and Oligochaeta. The higher abundance of Tanaidacea is related to environments rich in fine sediments with organic matter and the occurrence of this characteristics was determinant for the distribution of other taxa. The results indicate that the wet period favours the establishment of the benthic community, as evidenced by the increase in diversity and equitability.

Descriptors: Macroinvertebrates, Diversity, Unconsolidated substrate, Estuary.

\section{INTRODUCTION}

The Brazilian coast has a significant number of mangroves associated with estuaries and lagoons, accounting for $7 \%$ of the total number of mangroves

Submitted on: $27 /$ June/2019

Approved on: 24/January/2020

Associate Editor: Abilio S. Gomes

Editor: Rubens M. Lopes

(i) 2019 The authors. This is an open access article distributed under the terms of the Creative Commons license. throughout the world and third largest in terms of extension (FAO, 2007; Giri et al., 2011). The northern coast of the country accounts for 60 to $70 \%$ of the extension of this ecosystem and the coast of the states of Pará (PA) and Maranhão (MA) are home to the largest contiguous belt of these forests, covering 700,000 ha (Ferreira and Lacerda, 2016).

Natural ecosystems in coastal areas include estuaries, mangroves, lagoons, beaches, deltas and other environments of considerable ecological importance. Estuaries are partially closed by the permanent or 
periodic connection to the ocean. These ecosystems have lower salinity than the marine environment due to the input of freshwater and possess a very particular biota adapted to macrotidal pulses (Potter et al., 2010; Elliott and Whitfield, 2011). Estuaries are heterogeneous environments that provide highly diversified habitats. The biological assemblages in these environments are often used as indicators of natural and anthropogenic changes. Spatiotemporal variability in estuarine communities is determined by the climate, runoff patterns and ocean dynamics, which cause changes in nutrient content, primary production and the sediment. Therefore, the estuarine fauna must be highly adapted to deterministic and stochastic environmental changes and this ecosystem is inhabited by a diversity of benthic organisms that play an important role in the transference of matter and energy among different trophic levels (Egres et al., 2012; Bernardino et al., 2016).

Studies on composition and distribution of benthic macrofauna in relation to their habitat provide an initial perception with regard to the ecological processes that control communities and populations (Nanami et al., 2005; Silva et al., 2017). Among the biological components of the estuarine environment, the benthic community plays an important role in understanding the mechanisms of functioning of this ecosystem, as it more accurately reflects the conditions of the environment in which they live, mainly due to their way of life near the bottom and the predominance of forms of low mobility, which greatly accredit their use for diagnostics or environmental monitoring (Clarke and Warwick, 1994).

On the Brazilian northern coast, considerable gap is found with regard to the level of knowledge on the benthic macrofauna. Studies have mainly focused on subtropical estuaries (Monteiro Neto and Mendonça Neto, 2009; Amaral et al., 2013; Bernardino et al., 2016), whereas studies addressing tropical estuaries are scarce, with little information on the benthic fauna in the region (Ribeiro and Almeida, 2014), especially along the Amazonian coast. In these areas, despite their ecological and economic importance, the structure and functioning of benthic communities are virtually unknown (Lana et al., 1996; Capobianco et al., 2001), revealing the urgent need for studies to fill these gaps.
Among the numerous estuarine environments in the Gulf of Maranhão, the estuary of the Perizes River stands out. It is located between the São José Bay and São Marcos Bay, giving the environment a non-uniform distribution of sedimentary facies and a dynamism in the transport of reworked sediments by the tides. In the Perizes River estuary, there are no scientific records of the benthic macrofauna associated with environmental dynamics of estuary, which is therefore an unknown environment in terms of the bioecology of its benthic fauna.

The purpose of the present study was to describe the species composition and spatiotemporal distribution of the benthic macrofauna in the estuary of the Perizes River and identify environmental factors that determine the diversity and abundance patterns of its communities.

\section{MATERIALS AND METHODS}

\section{StUdY AREA}

The estuary of the Perizes River is located in the northeast portion of the municipality of Bacabeira at the city limits with the municipality of Rosário between coordinates $2^{\circ} 45^{\prime} 55^{\prime \prime} \mathrm{S}-2^{\circ} 50^{\prime} 55^{\prime \prime} \mathrm{S}$ and $44^{\circ} 19^{\prime} 43^{\prime \prime} \mathrm{W}-44^{\circ} 20^{\prime} 47^{\prime \prime} \mathrm{W}$. The estuary has an area of $10.48 \mathrm{ha}$ and a perimeter of $65.13 \mathrm{~km}$. It is located in a sustainable use conservation unit (Perizes River Extractivist Reserve) and consists of fluvial-marine systems composed of mangroves and salt marshes. The region has particular importance because it is inserted between two large bays: São Marcos and São José, which are considered the most important in the coastal zone of Maranhão due to their physiographic aspects, because they are the drainage of the largest rivers in the state. These two bays communicate across the Mosquito Strait, which along the Perizes River estuary still have conserved environmental status (Figure 1).

The region has a semi-diurnal macrotidal pattern. The maximum range reaches $7.5 \mathrm{~m}$ in the Gulf of Maranhão. The waters are typically estuarine and result from a mixture of freshwater from the Itapecuru/ Munim and Mearim Rivers, which respectively empty into the São José/Arraial and São Marcos Bays (Stride, 1992). 

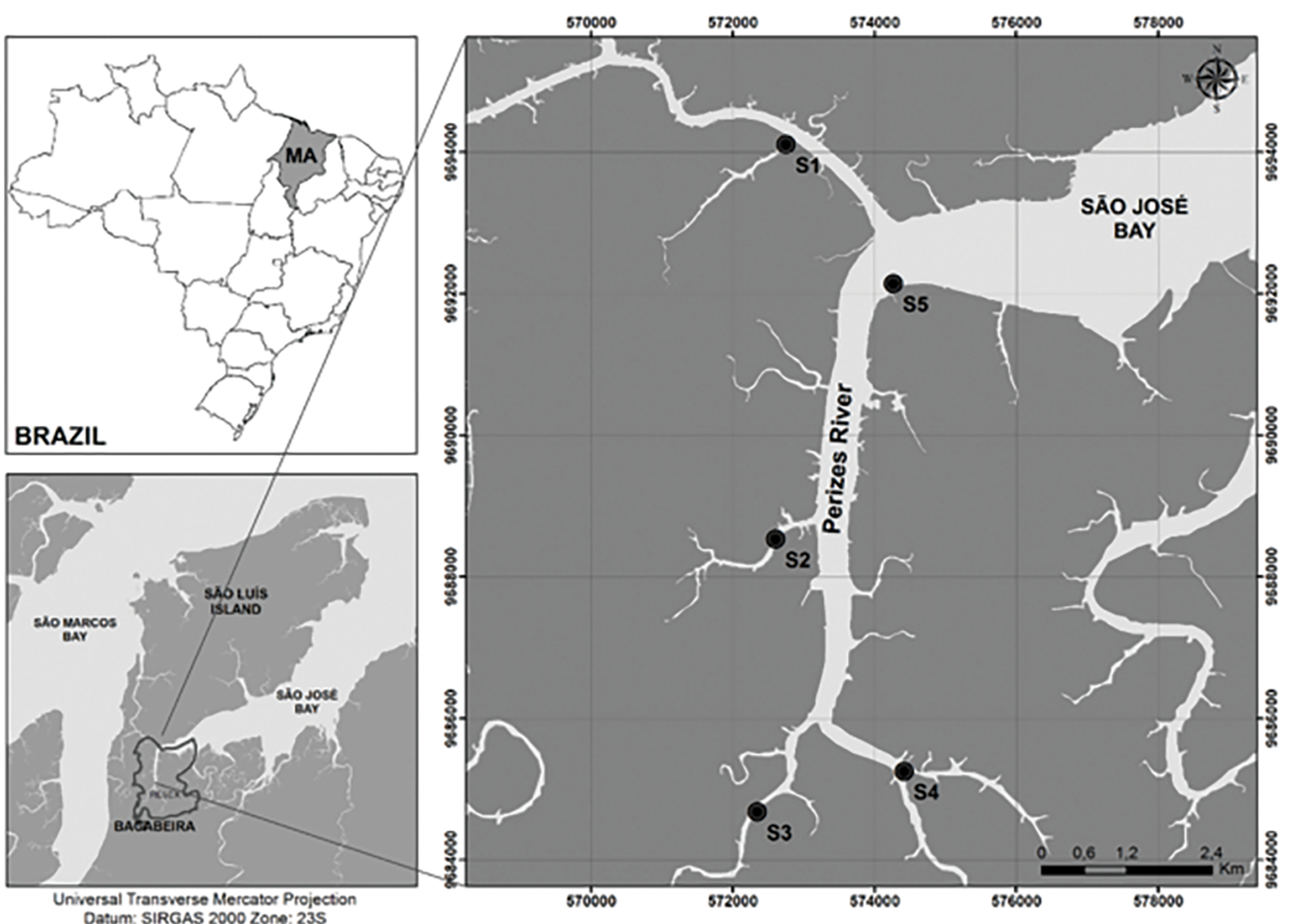

Figure 1. Map showing location of sampling sites in study area along estuary of Perizes River, state of Maranhão, Brazil.

Data obtained from the Brazilian Meteorology Institute (INMET: http//www.inmet.gov.br) from the station located in São Luis were used to record rainfall in the period from September 2016 to April 2017. Accumulated rainfall in the dry period was $1.8 \mathrm{~mm}$, which was recorded only in September 2016, whereas accumulated rainfall in the wet period was $1225.6 \mathrm{~mm}$, spanning the months of February $(413.8 \mathrm{~mm})$, March (472.2mm) and April 2017 (339.6mm) (INMET, 2017).

\section{FieLd AND LABORATORY PROCEDURES}

six sampling campaigns were conducted: three in the dry period (September, October and November 2016) and three in the wet period (February, March and April 2017). Five sampling sites (S1, S2, S3, S4 and S5) were distributed from outer to inner zones of the estuary at average depths between 1.0 and 1.5 meters. Three samples were collected in intertidal zone exposed to air during low tide using a van Veen grab sampler of $682 \mathrm{~cm}^{2}$ of sampling area: one for the analysis of the macrofauna, one for the granulometric analyses and one for the determination of organic matter and total organic carbon. The samples were placed in previously identified polyethylene bags and transported to the laboratory for subsequent analysis. The samples for the chemical analyses were placed in a cool box with ice. The material collected for the macrofauna analysis was fixed in $10 \%$ formalin.

In the field, the following physicochemical variables were collected from the subsurface of the water $(0.50 \mathrm{~m})$ with the aid of a HACH HQ40D multi-parameter probe: temperature $\left({ }^{\circ} \mathrm{C}\right), \mathrm{pH}$, salinity, dissolved oxygen $\left(\mathrm{mg} \mathrm{L}^{-1}\right)$, saturation (\%) and water transparency $(\mathrm{cm})$ using a Secchi disk until the depth at which the disk is no longer visible. In the laboratory, the granulometric analysis was performed following the method described by Suguio (1973). The sediment fractions were quantified using the pipetting method based on Stokes' law. The determination of total organic carbon and organic matter was performed using the modified Walkley-Black method (Gaudette et al., 1974).

The fauna samples were washed in a sieve with a $0.5 \mathrm{~mm}$ mesh and conserved in $70 \%$ alcohol with 
the addition of Rose Bengal. Identification was performed under a Zeiss Stemi DV4 stereomicroscope and Zeiss Primo Star optical microscope to the lowest possible taxonomic level with the aid of specialised literature.

\section{Data ANALYsis}

The physical and chemical variables water temperature, $\mathrm{pH}$, dissolved oxygen, salinity, transparency, organic matter, total organic carbon were submitted to univariate and multivariate statistical analysis. Species were classified into three categories using the constancy index (Dajoz, 1973): constant (> 50\%), accessory (50-25\%) and occasional ( $<25 \%)$, considering the sampling month in which the species was collected in relation to the total number of campaigns. Biological indices of abundance, species richness (S), Shannon-Wiener diversity $(\mathrm{H})$ and Pielou's evenness (J) were estimated.

The Shapiro-Wilk test and Levene's test were used for the determination of the normality of data distribution and equal variances, respectively. For data with equal variances, one-way analysis of variance was used for temporal comparation. For cases in which the null hypothesis of variance was rejected, Tukey's test was employed to identify which pairs of means differed statistically. For data with heterogeneous variances, the temporal comparation were performed using the Kruskal-Wallis test $(\mathrm{H})$, followed by the Mann-Whitney U-test for cases in which the null hypothesis was rejected.

Principal component analysis was used to identify the main components responsible for the variation in the environment variables in the estuary and correlations were determined using Pearson's correlation coefficient to identify which environmental variables were most closely related to the faunal distribution patterns. The analysis was performed using Pearson's correlation test with significance level of 0.05 . The distribution of the constant benthic macrofauna species (> 50\% of samples) and respective correlations with environmental variables were analysed statistically using canonical correspondence analysis (CCA). The environmental variables selected for this analysis were taken from a correlation matrix, in which variables with high collinearity were excluded, with the selection of the variable of greater importance to the organisms, thereby eliminating the redundancy of the data. Data on the abundance of organisms were log-transformed $(x+1)$ to reduce the influence of dominant species and environmental variables were normalised by mean $=0$ and standard deviation $=1$.

The Excel 2013, STATISTICA 7 and PAST 3.14 programs were used for analysis of the data (Hammer, 2016). All analyses were evaluated for a critical significance level of $\mathrm{a}=0.05$ (Zar, 2010).

\section{RESULTS}

\section{Physicochemical Variables}

Water temperature ranged from 26.8 ( $\mathrm{S} 3$ in Feb/2017) to $33.5^{\circ} \mathrm{C}$ (S5 in Mar/2017) (mean: 29.9 \pm 1.6 $\left.{ }^{\circ} \mathrm{C}\right)$. No significant differences were found among the sampling sites $\left(\mathrm{F}_{(4,25)}=0.7132 ; p=0.591\right)$. Among the campaigns, Feb/17 had the lowest temperature, differing significantly from the other campaigns $\left(\mathrm{H}_{(0.05,5)}=14.31 ; p=0.013\right)$ (Figure $\left.2 \mathrm{~A}\right)$.

The $\mathrm{pH}$ of the water fluctuated between 7.49 ( $\mathrm{S} 1$ in Sep/16) and 7.98 (S4 in Oct/16) (mean: 7.74 \pm 0.11 ). No significant differences were found among the sampling sites $\left(F_{(4,25)}=1.323 ; p=0.029\right)$. Among the campaigns, $\mathrm{pH}$ was significantly higher in Oct/16 compared to the other sampling campaigns $\left(\mathrm{F}_{(5,24)}=6.027\right.$; $p=0.0009$ ) (Figure 2B).

Salinity ranged from 4.9 (S3 in Mar/17) to 36.2 (S5 in Nov/16) (mean: 23.16 \pm 11.89 ). No statistically significant differences were found on the spatial scale $\left(F_{(4,25)}=0.007 ; p=0.999\right)$, but this variable was extremely dynamic on the temporal scale, with significant differences among the majority of campaigns $\left(\mathrm{H}_{(0.05,5)}=27.45 ; \quad p<0.005\right)$, except between Mar/17 and April/17, which had the lowest mean salinity values and did not differ significantly from each other (Figure 2C).

Dissolved oxygen ranged from 2.62 (S4 in Feb/17) to $6.8 \mathrm{mg} \mathrm{L}^{-1}$ (S4 in Nov/16) (mean: $4.70 \pm 1.25 \mathrm{mg} \mathrm{L}^{-1}$ ). No statistically significant differences were found on the spatial scale $\left(\mathrm{F}_{(4,25)}=0.183 ; p=0.945\right)$. However, significant differences were found on the temporal scale $\left(\mathrm{H}_{(0.05,5)}=22.74 ; p<0.05\right)$, with higher values in Nov/16 compared to the other campaigns (Figure 2D). Likewise, no significant differences were found in saturation on the spatial scale $\left(\mathrm{H}_{(0.05,4)}=0.401 ; p=0.982\right)$, but differences were found on the temporal scale $\left(\mathrm{H}_{(0.05,5)}=21.89 ; p<0.05\right)$, with the largest difference 

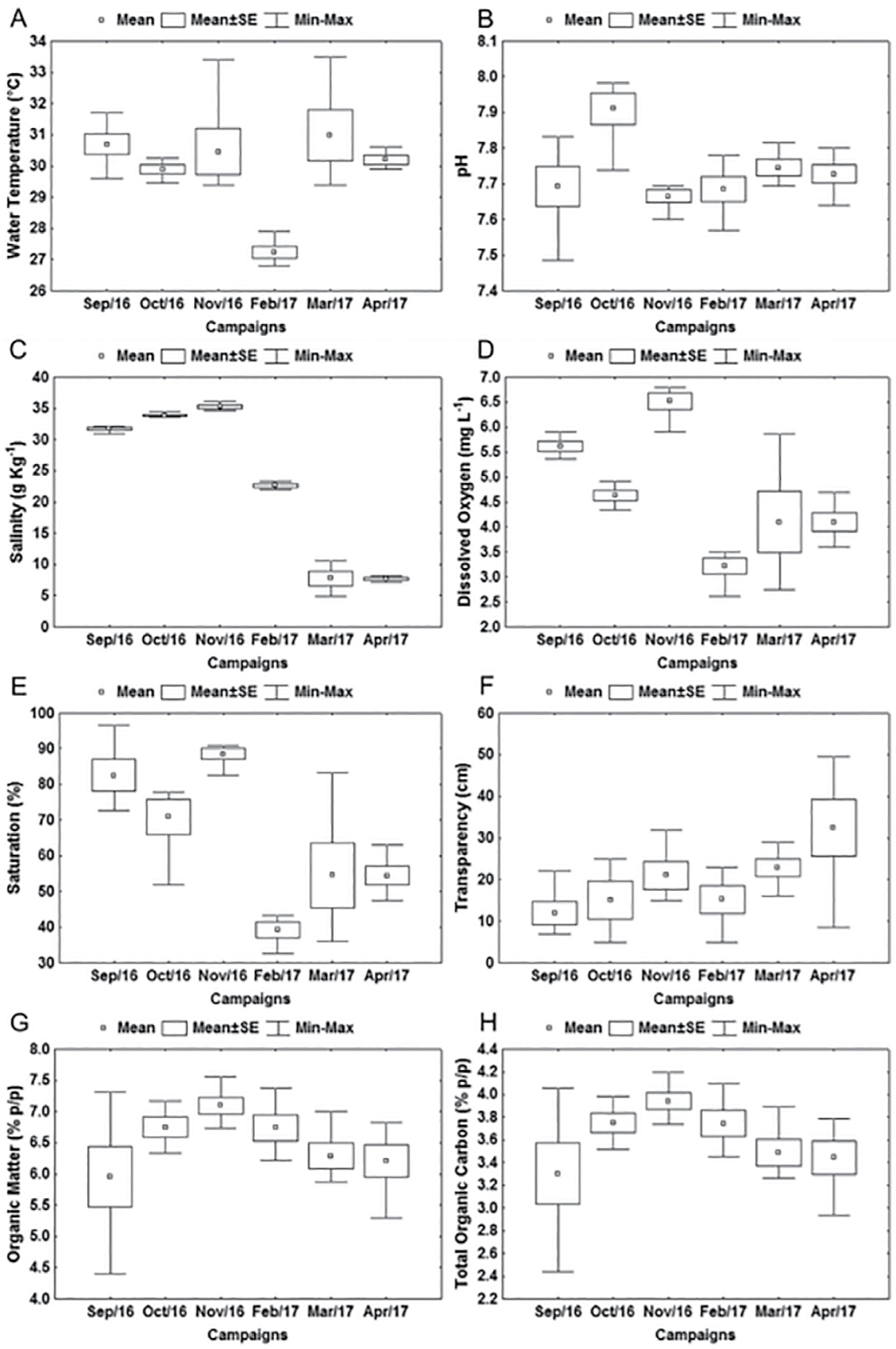

Figure 2. Boxplot of environmental variables with mean, minimum, maximum and standard error (SE) values during campaigns in estuary of Perizes River. (A) Water temperature, $(B)$ pH of water, $(C)$ salinity, $(D)$ dissolved oxygen, (E) saturation, $(F)$ transparency, $(G)$ organic matter, $(H)$ total organic carbon.

found between Nov/16 (highest value) and Feb/17 (lowest value) (Figure 2E).

Transparency ranged from 5.0 (S5 in Oct/16) to $49.5 \mathrm{~cm}$ (S1 in April/17) (mean: $19.9 \pm 10.73 \mathrm{~cm}$ ). No significant differences were found on the spatial scale $\left(\mathrm{F}_{(4,25)}=0.667 ; p=0.621\right)$. On the temporal scale, a significant difference was found between Sep/16 and April/17 $\left(\mathrm{F}_{(5,23)}=3.306 ; p=0.021\right)$ (Figure 2F).

Similar mean concentrations of organic matter were found among the sampling sites, ranging from 4.4\% (S5 in Sep/16) to 7.56\% (S2 in Nov/16) (mean: $6.51 \pm 0.68 \%)$, with no significant spatial differences 
$\left(\mathrm{H}_{(0.05,4)}=0.503 ; p=0.973\right)$. No significant differences were found in the temporal evaluation $\left(F_{(5,24)}=2.525\right.$; $p=0.056$ ), but an increasing gradient was found in the dry period, whereas a decreasing gradient was found in the wet period (Figure $2 \mathrm{G}$ ). The same occurred with total organic carbon content (Figure $2 \mathrm{H}$ ), which ranged from $2.44 \%$ (S5 in Sep/16) to 4.2\% (S3 in Nov/16) (mean: $3.61 \pm 0.38 \%)$, with no significant differences on either the spatial $\left(\mathrm{H}_{(0.05,4)}=0.433 ; p=0.979\right)$ or temporal $\left(\mathrm{F}_{(5,24)}=2.538 ; p=0.056\right)$ scale. The highest organic matter $(7.56 \%)$ and total organic carbon (4.2\%) concentrations were found in Nov/16, in which no rainfall occurred (Figure 2G).

The study area was characterized by the predominance of coarse silt throughout the profile of the estuary, ranging from $78.83 \%$ (S3 in Mar/17) to $99.83 \%$ (S5 in April/17). Small amounts of medium coarse, fine and very fine silt as well as clay were also found in the sediment.
In the principal component analysis of the environmental variables, the first two axes explained $57.7 \%$ of the total variability in the data (Figure 3 ). The significance of the axes was tested using the "broken stick" randomisation model with 9999 replications per bootstrap (Jackson, 1993), which indicated that Components 1 and 2 were sufficient to represent factor variance.

The projection plane of the scores revealed the formation of two groups. A natural well-defined seasonal variation pattern was found, demonstrating the influence of the dry period on the projection of the variables positioned in the positive quadrant of Axis 1, whereas the wet period exerted an influence on the positioning of the scores in the negative quadrant of Axis 1 (Figure 3).

The bi-factor plane revealed that the positively correlated variables in Component 1 (32.8\%) were salinity, dissolved oxygen and saturation. These

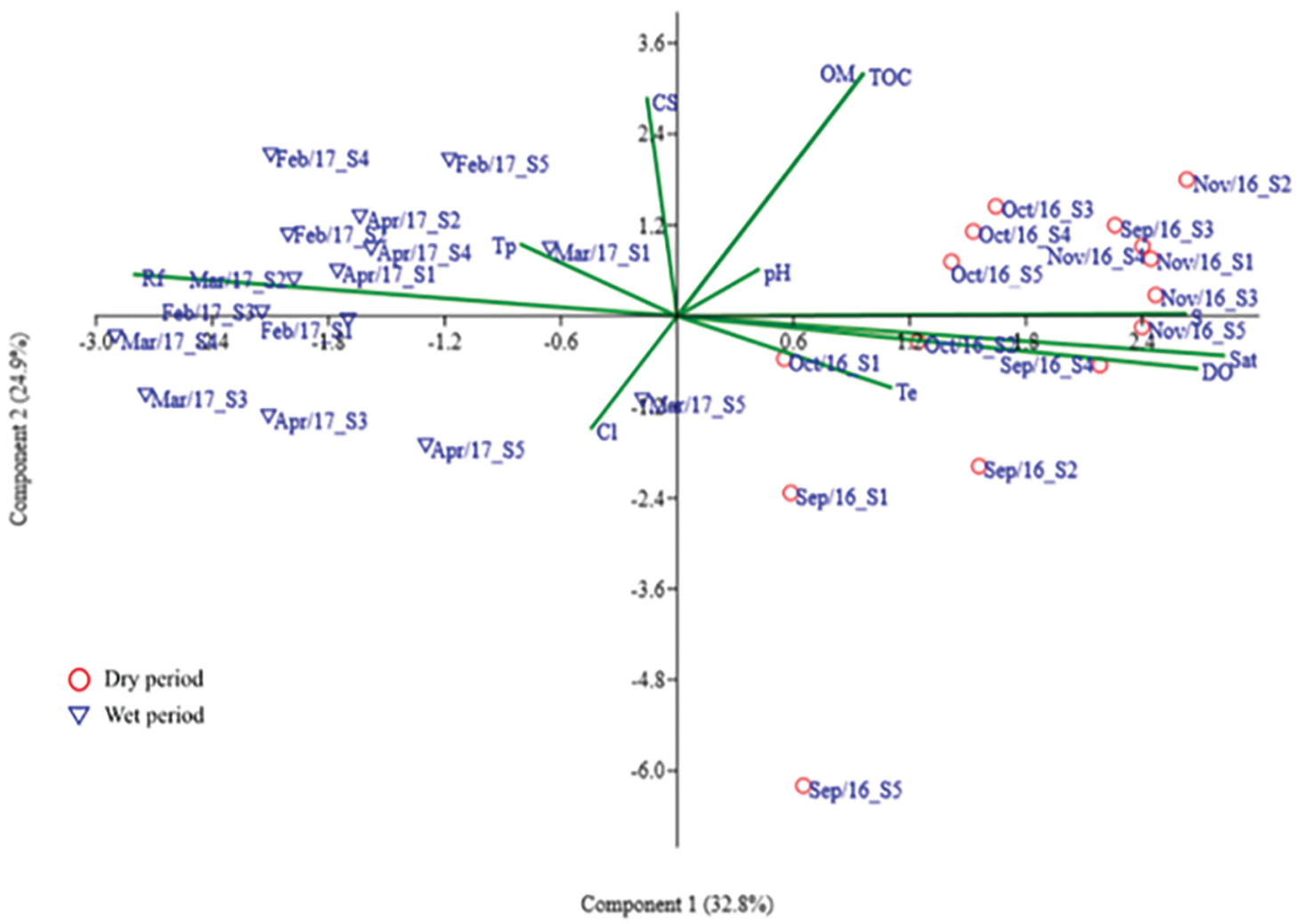

Figure 3. Principal component analysis of environmental variables in study area. $\mathrm{Te}=$ water temperature, $\mathrm{S}=$ salinity, $\mathrm{DO}=$ dissolved oxygen, $\mathrm{Sat}=$ saturation, $\mathrm{Tp}=$ transparency, $\mathrm{Rf}=$ rainfall, $\mathrm{CS}=$ coarse silt, $\mathrm{Cl}=$ clay, $\mathrm{OM}=$ organic matter, $\mathrm{TOC}=$ total organic carbon. 
variables were more strongly associated with $\mathrm{Sep} / 16$, Oct/16 and Nov/16. Rainfall was negatively correlated with Component 1 and was associated with Feb/17, Mar/17 and April/17. The variables most correlated with Component 2 (24.9\%) were coarse silt, organic matter and total organic carbon.

\section{Macrofauna COMPOSITION}

A total of 35,597 individuals of the benthic macrofauna belonging to 84 species and 29 taxonomic groups were identified in the estuary of the Perizes River. Tanaidacea exhibited the greatest abundance $(84.28 \%)$, followed by Oligochaeta $(4.61 \%)$ and Polychaeta (3.16\%). These three groups accounted for more than $92 \%$ of the total abundance of macrofauna, whereas the other groups together did not surpass $8 \%$ of the total number of individuals sampled, demonstrating that the environment is dominated by a small number of groups. With regard to richness, Polychaeta was the most representative group (21 species), followed by Diptera (17 speces), Bivalvia (six species) and Gastropoda (five species). The remaining groups were represented by less than five species.

The most abundant organisms were Monokalliapseudes schubarti, Oligochaeta, Nematoda, Acari, Ostracoda, Ceratopogonidae sp., Polychaeta, Heteromastus sp. and Notomastus sp., accounting for $95 \%$ of the total number of individuals. Regarding constancy in the samples, $26.19 \%$ of the species were classified as constant, $35.71 \%$ were classified as accessory and $39.29 \%$ were classified as occasional, demonstrating that the largest portion of the species were considered rare in this environment. Monokalliapseudes schubarti, Nemertea, Oligochaeta, Sipuncula, Collembola, Acari, Ostracoda, Nematoda, Polychaeta Alitta succinea, Sigambra grubei, Notomastus sp., Heteromastus sp., Diptera Dolichopodidae sp. and Ceratopogonidae sp. occurred in all campaigns conducted in the present study (Table 1).

No significant differences among sampling sites were found for the biological indices (abundance, richness, evenness and diversity) (Table 2). In contrast, significant differences in all indices, except richness, were found among the sampling campaigns. With regard to abundance, the number of individuals recorded in Feb/17 differed from the number recorded in
Sep/16 and Oct/16. Moreover, the number of individuals recorded in April/17 differed from the number recorded in Oct/16 (Figure 4). Significant differences in evenness were found between Sep/16 and both Feb/17 and April/17 as well as between Oct/16 and April/17. Species diversity followed a similar pattern as that found for evenness, with higher values in the wet period compared to the dry period.

Despite the lack of significant differences among the sampling sites, $\mathrm{S} 2$ had the highest number of individuals, followed by $\mathrm{S} 5$, whereas the smallest number of organisms was recorded at $S 1$. Richness was highest at S3 and S4, whereas the lowest number of species was recorded at S5. Representatives of Oligochaeta were abundant at all sites and Tanaidacea were also prominent in the estuary, except at S1. Acari were abundant in the inner area of the estuary (S3 and S4), whereas the number of Ostracoda was high in the outer area (S1 and S5).

Pearson's correlation matrix between environmental variables and constant species revealed negative correlations among salinity, rainfall, Heteromastus sp. and Muscidae. The strongest correlations were found between clay and both organic matter and total organic carbon. A. succinea was negatively correlated with total organic carbon, $A$. flexuosa, Dolichopodidae and Collembola. L. culveri and Tabanidae were significantly correlated with M. schubarti. The capitellids Notomastus sp. and Heteromastus sp. were correlated with the dipterans Dolicopodidae, Muscidae and Tabanidae (Table 3).

The canonical correspondence analysis (CCA) explained $74.4 \%$ of the relationships between species and environmental variables. Rainfall, dissolved oxygen and salinity made the largest contributions to the formation of Axis 1, which explained $40.0 \%$ of the distribution of the samples. Organic matter had the strongest weight in the formation of Axis 2, which explained $34.4 \%$ of the variation (Figure 5).

Axis 1 shows that $M$. schubarti, Oligochaeta, Nemertea, Nematoda, Sipuncula, L. culveri and S. grubei were more abundant when the concentration of dissolved oxygen and salinity were higher. Ostracoda, Heteromastus sp., Notomastus sp., Muscidae and Tabanidae were more strongly associated with rainfall, indicating that these species are more constant in the wet period in the study area. Regarding Axis 2, A. flexuosa and Collembola were strongly correlated 
Table 1. Constancy of species sampled in estuary of Perizes River.

\begin{tabular}{|c|c|c|c|c|c|}
\hline Species & Constancy & Species & Constancy & Species & Constancy \\
\hline Nemertea & $100,00 \%$ & Eurytellina lineata & $33,33 \%$ & Melampus coffea & $16,67 \%$ \\
\hline Oligochaeta & $100,00 \%$ & Mytella charruana & $33,33 \%$ & Gastropoda sp. & $16,67 \%$ \\
\hline Alitta succinea & $100,00 \%$ & Bivalve sp1 & $33,33 \%$ & Phyllodoce sp. & $16,67 \%$ \\
\hline Sigambra grubei & $100,00 \%$ & Nudibranchia & $33,33 \%$ & Mageloma papillicornis & $16,67 \%$ \\
\hline Notomastus sp. & $100,00 \%$ & Scaphopoda & $33,33 \%$ & Isolda pulchella & $16,67 \%$ \\
\hline Heteromastus sp. & $100,00 \%$ & Syllis sp. & $33,33 \%$ & Sipuncula sp2 & $16,67 \%$ \\
\hline Sipuncula sp1 & $100,00 \%$ & Scoletoma tetraura & $33,33 \%$ & Sipuncula sp3 & $16,67 \%$ \\
\hline Ceratopogonidae & $100,00 \%$ & Aricidea (Acmira) taylori & $33,33 \%$ & Ceratopogonidae sp2 & $16,67 \%$ \\
\hline Dolichopodidae & $100,00 \%$ & Scoloplos sp. & $33,33 \%$ & Ceratopogonidae sp3 & $16,67 \%$ \\
\hline Colembola & $100,00 \%$ & Capitomastus sp. & $33,33 \%$ & Diptera sp3 & $16,67 \%$ \\
\hline Ácaro & $100,00 \%$ & Mediomastus sp. & $33,33 \%$ & Diptera sp4 & $16,67 \%$ \\
\hline Tanaidacea & $100,00 \%$ & Chone sp. & $33,33 \%$ & Diptera sp5 & $16,67 \%$ \\
\hline Ostracoda & $100,00 \%$ & Chironomidae & $33,33 \%$ & Ptilodactylidae & $16,67 \%$ \\
\hline Nematoda & $100,00 \%$ & Tabanidae sp2 & $33,33 \%$ & Minuca burgersi & $16,67 \%$ \\
\hline Capitella sp. & $83,33 \%$ & Tabanidae sp3 & $33,33 \%$ & Sesarma crassipes & $16,67 \%$ \\
\hline Muscidae sp1 & $83,33 \%$ & Muscidae sp2 & $33,33 \%$ & Sphaeromatidae & $16,67 \%$ \\
\hline Nematomorpha & $83,33 \%$ & Psychodidae & $33,33 \%$ & Isopoda & $16,67 \%$ \\
\hline Anomalocardea flexuosa & $66,67 \%$ & Phoridae & $33,33 \%$ & Amphipoda sp2 & $16,67 \%$ \\
\hline Laeonereis culveri & $66,67 \%$ & Diptera sp1 & $33,33 \%$ & Amphipoda sp3 & $16,67 \%$ \\
\hline Streblospio benedicti & $66,67 \%$ & Diptera sp2 & $33,33 \%$ & Monocorophium acherusicum & $16,67 \%$ \\
\hline Tabanidae sp1 & $66,67 \%$ & Dytiscidae & $33,33 \%$ & Bowmaniella brasiliensis & $16,67 \%$ \\
\hline Blauneria sp. & $50,00 \%$ & Uca (Uca) maracoani & $33,33 \%$ & Arthropoda & $16,67 \%$ \\
\hline Namalycastis abiuma & $50,00 \%$ & Amphipoda sp1 & $33,33 \%$ & Bryozoa & $16,67 \%$ \\
\hline Nephtys fluviatilis & $50,00 \%$ & Actiniaria & $16,67 \%$ & Chaetognata & $16,67 \%$ \\
\hline Paraonis sp. & $50,00 \%$ & Turbellaria & $16,67 \%$ & Hemichordata & $16,67 \%$ \\
\hline Scoloplos (Leodamas) rubra & $50,00 \%$ & Tagelus plebeus & $16,67 \%$ & Tunicata & $16,67 \%$ \\
\hline Mesoveliidae & $50,00 \%$ & Crassostrea sp. & $16,67 \%$ & Foraminifera & $16,67 \%$ \\
\hline Cnidaria & $33,33 \%$ & Rissoella caribaea & $16,67 \%$ & Foraminifera sp2 & $16,67 \%$ \\
\hline
\end{tabular}

Table 2. Results of analysis of variance for biotic indices.

\begin{tabular}{lcccc}
\hline \multirow{2}{*}{ Indices } & \multicolumn{2}{c}{ Spatial } & \multicolumn{2}{c}{ Temporal } \\
& $\mathbf{F}_{(4,25)}$ & $\mathbf{p}$ & $\mathbf{F}_{(5,24)}$ & $\mathbf{p}$ \\
\hline Richness & 2.183 & 0.1002 & 2.005 & 0.1143 \\
Abundance & 0.3472 & 0.846 & 12.56 & $0.0086^{*}$ \\
Evenness & 0.3617 & 0.8385 & 3.19 & $0.024^{*}$ \\
Diversity & 0.4489 & 0.7722 & 4.645 & $0.00417^{*}$ \\
\hline
\end{tabular}

* Significant difference $(p<0.05)$.

with organic matter. The distribution of the other taxa sampled did not enable any associations with the variation gradient of the environmental variables used in the CCA.

\section{DISCUSSION}

The temperature and rainfall patterns recorded in the estuary of the Perizes River were characteristic of tropical environments, with higher temperatures and lower rainfall during the Sep/16, Oct/16 and Nov/16 campaigns and, consequently, an increase in salinity. Silva et al. (2011) report similar results for Caeté estuary in northern Brazil. Accordingly, rainfall during the Feb/17, Mar/17 and April/17 campaigns led to an increase in freshwater input, resulting in a reduction in salinity, which is similar to the findings described for the Amazonian coast (Carvalho-Neta and Castro, 2008; Braga et al., 2011; Sousa et al., 2015). 

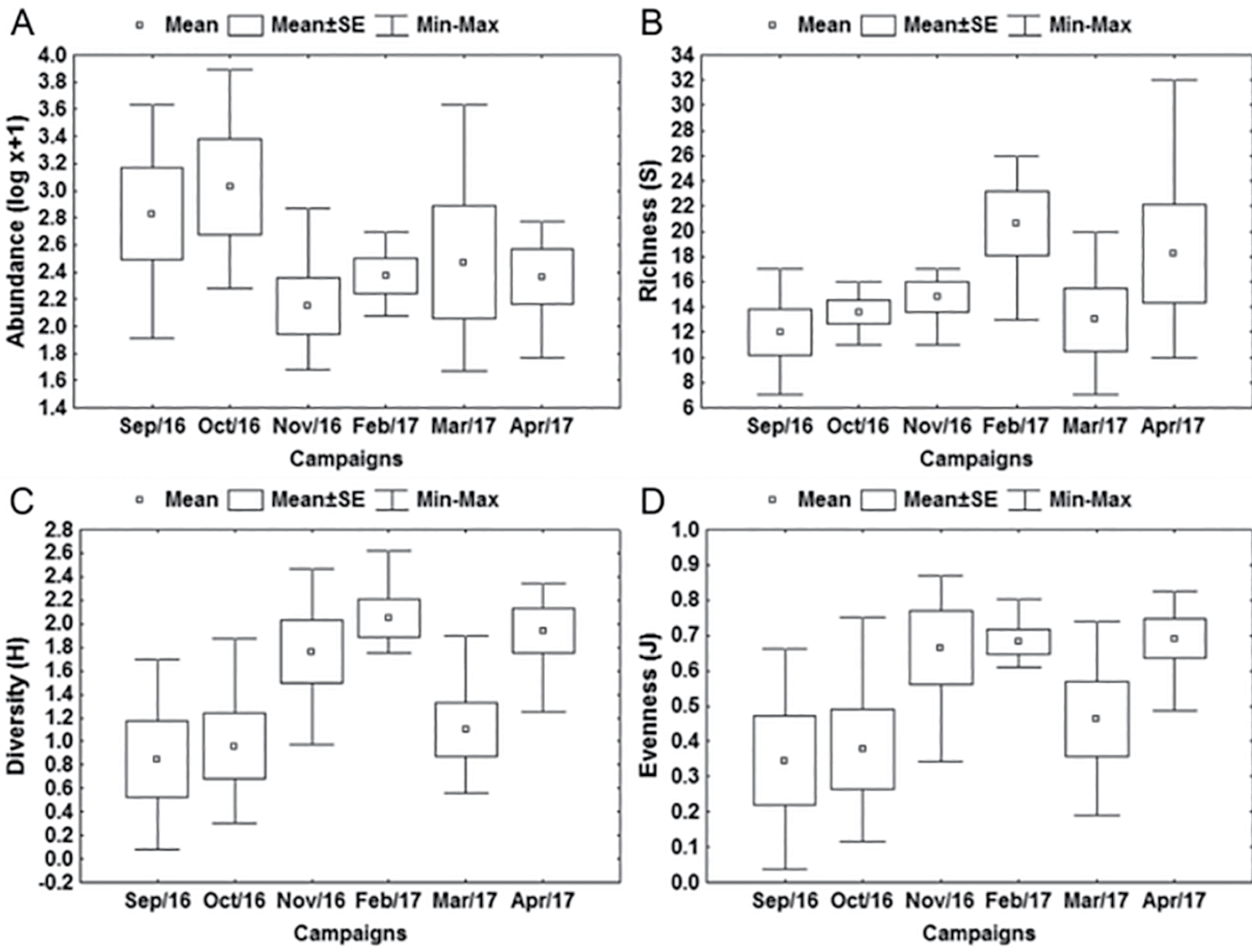

Figure 4. Variation in biotic indices throughout sampling campaigns in estuary of Perizes River, Maranhão, Brazil. (A) Abundance, (B) Richness, (C) Diversity, (D) Evenness.

High salinity (20 to 35 ) was found in the dry period from the mouth of the estuary to approximately $9 \mathrm{~km}$ upriver, demonstrating the reduction in freshwater input. The lowest mean salinity (7.76) was recorded during the Mar/17 campaign, which was the period of greatest rainfall in the region, with $472.2 \mathrm{~mm}$ reported for the month (INMET, 2017). In contrast, low rainfall contributed to the increase in salinity, with the highest mean (35.26) found during the Nov/16 campaign. Changes in salinity in tropical estuaries alter the structure of macrobenthic communities, as the dynamics of these ecosystems are controlled by variations in hydrology, morphology and the physicochemical conditions the marine and freshwater environments (Day Junior et al., 2013).

The dominant groups in the community of this estuary were Tanaidacea, Oligochaeta and Polychaeta, revealing that a small number of groups dominates the environment. This differs from the composition of other estuarine communities along the coast of the state of Maranhão, Brazil, where the taxocoenosis has a dominance of Polychaeta, Mollusca and Bivalvia (Mackie and Oliver, 1996; Oliveira and Mochel, 1999; Mochel, 2011). In contrast to abundance, the dominant groups in terms of species richness were Polychaeta, Diptera and Bivalvia.

Jourde et al. (2017) studying macrobenthic communities in the Guiana's coast point out that only 38 taxa were recorded, among which two groups were common and widely distributed: Tanaid and Polychaete. This study suggests that the differences in macrofaunal community composition among sites could be due to the migration stage of banks rather than the distance from the Amazon Delta and associated effects of river discharge. The abundance of benthic organisms found in the estuary of the Perizes River was larger than that recorded in other studies conducted on the coast of the state of Maranhão as well as 


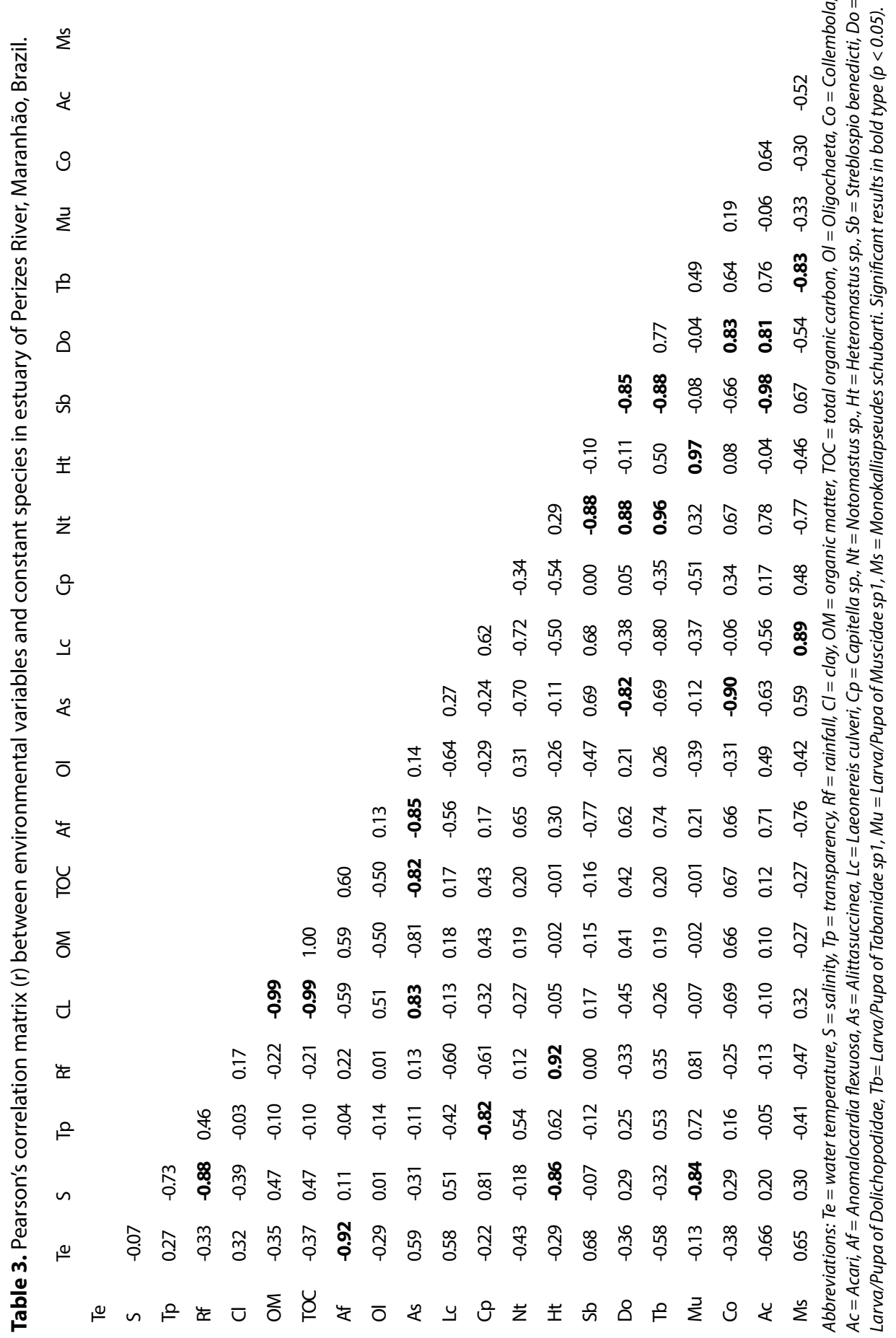

in other tropical estuaries (Oliveira and Mochel, 1999; Mochel et al., 2001; Lucero et al., 2006; Braga et al., 2011; Sousa et al., 2015; Rodrigues et al., 2016), since the studies cited were conducted in impacted environments and addressed specific groups of organisms. Similar abundance to that found in the present investigation was recorded for the estuary of Patos Lagoon in southern Brazil, where 38,827 individuals were found (Rosa and Bemvenuti, 2006), although one should bear in mind that the environmental conditions of this estuary differ from those found in the tropical region. In contrast, richness was not as 


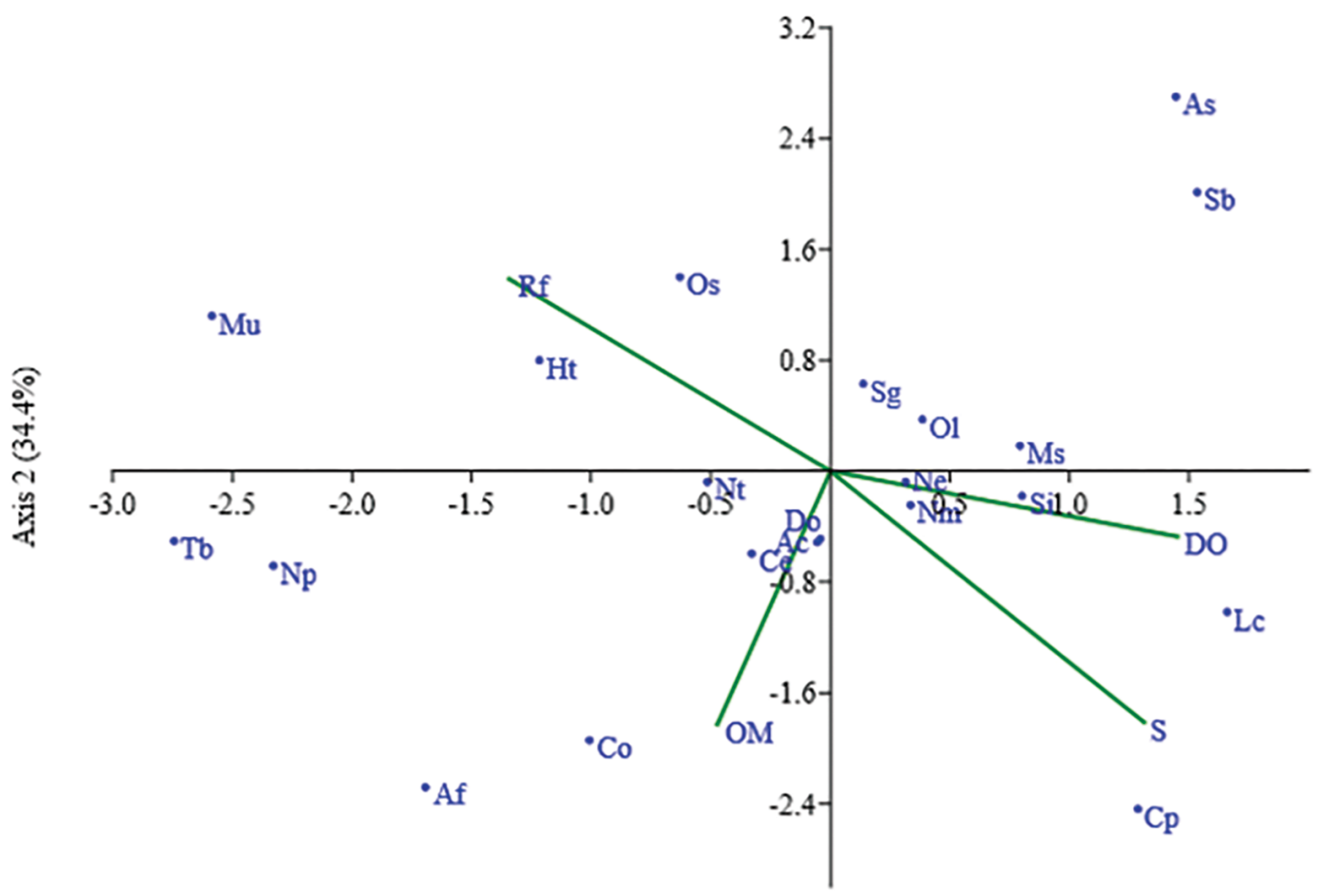

Axis $1(40.0 \%)$

Figure 5. Results of canonical correspondence analysis of environmental variables and constant species. Abbreviations: $S=s a l i n i t y, D O=$ dissolved oxygen; $\mathrm{Rf}=$ rainfall, $\mathrm{OM}=$ organic matter, $\mathrm{Ne}=$ Nemertea, $\mathrm{Ol}=$ Oligochaeta, $\mathrm{Si}=$ Sipuncula sp1, $\mathrm{Co}=\mathrm{Collembola}, \mathrm{Ac}=\mathrm{Acari}, \mathrm{Os}=$ Ostracoda, $\mathrm{Nm}=$ Nematoda, $\mathrm{Np}=$ Nematomorpha, $\mathrm{Af}=$ Anomalocardia flexuosa, As = Alitta succinea, $\mathrm{Lc}=$ Laeonereis culveri, $\mathrm{Sg}=\mathrm{Sigambra}$ grubei, $\mathrm{Cp}=$ Capitella sp., $\mathrm{Nt}=$ Notomastus sp., $\mathrm{Ht}=$ Heteromastus sp., $\mathrm{Sb}=$ Streblospio benedicti, $\mathrm{Ce}=\mathrm{Larva} /$ Pupa of Ceratopogonidae, $\mathrm{Do}=$ Larva/Pupa of Dolichopodidae, Tb = Larva/Pupa of Tabanidae sp1, Mu = Larva/Pupa of Muscidae sp1, Ms = Monokalliapseudes schubarti.

significant in the estuary of Patos Lagoon; the organisms were distributed among only 18 species, whereas 84 species were recorded in the estuary of the Perizes River. Among the dominant groups in the present investigation, Tanaidacea accounted for $84.28 \%$ of the abundance of macrofauna. In Patos Lagoon, Tanaidacea was also among the dominant groups, accounting for $24.7 \%$ of the total abundance of the macrofauna (Rosa and Bemvenuti, 2006).

The presence of Tanaidacea is restricted to intertidal environments near rivers or mangroves that are rich in fine sediments, as occurs in the estuary of the Perizes River (Bemvenuti, 1987; Leite, 1995; Leite et al., 2003; Lucero et al., 2006). Such characteristics result in a high density of these organisms, which have highly aggregated distribution, making them dominant species (Bemvenuti et al., 1978; Capitoli et al., 1978; Bemvenuti, 1987; Lana et al., 1989; Martins et al., 1989; Bemvenuti et al., 1992). The abundance of these organisms is related to high concentrations of organic matter, which serves as a food source (Bemvenuti, 1987; Leite, 1995; Leite et al., 2003). In the present study, however, organic matter was inversely correlated with the tanaid $M$. schubarti, as demonstrated in the CCA, which is in agreement with the result described by Freitas Júnior et al. (2013), who report that the development of species may be affected by high concentrations of organic matter as a result of the reduction in the availability of oxygen, leading to low densities.

Tanaidacea was also the dominant group in number of individuals in the estuary of the Dagua River on the coast of Colombia (Lucero et al., 2006), although the considerable density was attributed to 
the reduction in salinity. In contrast, the reduction in salinity in the estuary of the Perizes River resulted in the reduction in the abundance of these organisms. On the other hand, Tanaidacea is a large group, composed by different species, which can explain the different responses to environmental conditions, resulting in decreased abundance. Predator-prey interactions may also explain the change in the number of the tanaid M. schubarti (Menge, 1995; Nguyen et al., 2018), since the wet season favours an increase in the number of predators in search of food, as described in studies conducted by Hamilton et al. (2006), Cheverie et al. (2014) and Nguyen et al. (2018). M. schubarti is part of the diet of the fishes Centropomus parallelus and Micropogonias furnieri as well as other crustaceans and birds (Barreiros et al., 2009; Freitas Júnior, 2013), which are quite common in the estuary of the Perizes River.

Oligochaeta also made a significant contribution to the composition of the benthic community, ranking as the second most abundant group. The dominance of Oligochaeta is due to its capacity to tolerate environmental conditions that are considered hostile to other organisms and respond to organic enrichment with intensive asexual reproduction, resulting in a rapid increase in its population within a short time period (Giere and Pfannkuche, 1982 apud Aviz et al., 2012).

Silva et al. (2011) analysing the macrofauna in the Caeté estuary, northern Brazil coast, recorded 83 taxa belonging to six phyla, with Annelids dominating both in the dry and rainy seasons. In the rainy season, richness and diversity increased towards the estuary mouth. The authors pointed out that salinity was the most important environmental factor in the establishment of the macrobenthic community.

In the Guajará estuary located on the Amazon coast, high densities of Oligochaeta were associated with areas of organically enriched muddy sediment (Aviz et al., 2012), which is a common pattern in estuaries and marine habitats in tropical regions (Pagliosa and Barbosa, 2006; Ferrando and Méndez, 2011). Moreover, this estuary was dominated by a small number of taxa, as occurred in the estuary of the Perizes River, where Tanaidacea accounted for more than $80 \%$ of total abundance. The low diversity and dominance of few taxa in the Guajará estuary was attributed to low salinity, which hinders osmotic balance. However, diversity in the estuary of the Perizes River was greater when salinity was lower. It is believed that the diversity high during the wet season is likely linked to the fine sediment transported by the Mearim River and retained in the mangroves.

Capitellidae included detritivorous and opportunistic species of Polychaeta, the occurrence of which is associated with organic enrichment and fine sediments, which are normally found in disturbed areas (Ourives et al., 2011; Jumars et al., 2015). In the present study, this family was represented by Notomastus sp. and Heteromastus sp., which were more abundant in periods of greater rainfall (Feb/17, Mar/17 and April/17). This finding may be related to the input of detritus transported by the rain from the surrounding mangroves (Ourives et al., 2011). It is important to point out that the abundance of Capitella sp., which also belongs to this family, was significantly reduced in the wet period. This species is normally found in environments enriched with organic matter and is considered a bioindicator (Del-Pilar-Russo et al., 2008; Jumars et al., 2015).

The high abundance of Capitellidae is indicative of an environment with high concentrations of organic matter of a natural or anthropogenic origin, as these organisms are non-selective detritus consumers with a tendency to live in population clusters in all stages of development and some exhibit tolerance to extreme environmental changes (Amaral and Nonato, 1996; Amaral et al., 1998; Dittman, 2002).

Differences in the distribution of the benthic community among sampling sites are normally due to variations in the physicochemical variables of the water and sediment (Day Junior et al., 2013). However, no significant difference in spatial distribution was found in the benthic macrofauna in the estuary of the Perizes River. This indicates a relatively homogeneous environment with no well-defined gradients, which may be attributed to the intense hydrodynamics of the estuary (Aviz et al., 2012). In contrast, marked temporal differences in abundance, evenness and diversity were found in the benthic macrofauna community throughout the sampling campaigns. Abundance was generally higher in the dry period compared to the wet period, as demonstrated by the CCA, due mainly to the considerable dominance of $M$. schubarti in the environment, which was reflected in 
a reduction in evenness and, consequently, diversity. These indices were higher during the campaigns conducted in the wet period, when the abundance of the tanaid M. schubarti was lower, reflecting in more even distribution and greater diversity.

The effect of the abundance of these organisms on the structure and composition of the macrofauna has been reported in studies conducted in other tropical estuaries (Lucero et al., 2006). Such temporal changes are associated with rainfall and the variation in salinity, which exert a positive impact on the macrofauna, resulting in an increase in the density, biomass and/or diversity of species tolerant to conditions of low salinity (Montagna and Yoon, 1991; Montagna and Kalke, 1992; Aviz et al., 2012) as well as changes in distribution (Thurman et al., 2010; Condie et al., 2012). Authors have attributed the increase in the diversity of macrofauna in the wet season to the reduction in salinity and greater input of freshwater with organic enrichment due to the release of sediments, nutrients and pollutants (Kennish, 1997; Kimmerer, 2002; Carvalho et al., 2011; Aviz et al., 2012). In contrast, the dry season is associated with a reduction in diversity and abundance in benthic communities in environments with high salinity (Dauer et al., 2008).

The sediment in the estuary of the Perizes River was predominantly composed of fine particles, silt and clay, which is a common finding in estuaries of the Amazonian coastal zone (Braga et al. 2011; Aviz et al., 2012), suggesting that the occurrence and distribution of the benthic macrofauna are not related to the type of sediment. Although sediment characteristics are often reported to be important to the structure of the macrofauna (Whitlatch, 1981), factors such as predation, competition, bioturbation and environmental disturbances may also play an important role in the maintenance of the spatial and temporal heterogeneity of the macrofauna (Anderson, 2008; Newell et al., 2001; Snelgrove and Butman, 1994). The results found suggest that the temporal fluctuations in the macrobenthic community in the Perizes river estuary may be associated with variations in the environmental conditions linked to the seasonality that characterizes the rainy and dry seasons.

\section{ACKNOWLEDGMENTS}

The authors are grateful to the Coordenação de Aperfeiçoamento de Pessoal de Nível Superior (CAPES
[Coordination for the Advancement of Higher Education Personnel]) for awarding a study grant; the Laboratório de Ictiologia of the Universidade Federal do Maranhão and the Laboratório de Hidrodinâmica Costeira, Estuarina e de Águas Interiores (LHiCEAI [Laboratory of Coastal, Estuarine and Inland Water Hydrodynamics]) for authorizing the use of its installations for the analyses; to doctoral student James Werllen de Jesus Azevedo for assistance in the statistical analysis and Josinete Sampaio Monteles for assistance in the identifications.

\section{AUTHOR CONTRIBUTIONS}

H.R.S.F.: Conceptualization; Data curation; Formal analysis; Investigation; Methodology; Project administration; Supervision; Validation; Visualization; Writing - original draft; Writing review \& editing.

A.C.L.C.: Conceptualization; Formal analysis; Writing original draft; Writing - review \& editing.

M.V.J.C.: Writing - original draft; Writing - review \& editing.

V.M.O.: Investigation; Writing - review \& editing.

\section{REFERENCES}

AMARAL, A. C. Z. \& NONATO, E. F. 1996. Anellida Polychaeta: Características, glossário e chaves para famílias e gêneros da costa brasileira, Campinas, Editora da UNICAMP.

AMARAL, A. C. Z., MORGADO, E. H. \& SALVADOR, L. B. 1998. Poliquetas bioindicadores de poluição orgânica em praias paulistas. Revista Brasileira de Biologia, 58, 2, 307-316.

AMARAL, A. C. Z., NALLIN, S. A. H., STEINER, T. M., FORRONI, T. O. \& GOMES, D. F. 2013. Catálogo das espécies de Annelida Polychaeta do Brasil, Campinas, UNICAMP.

ANDERSON, M. J. 2008. Animal-sediment relationships re-visited: characterizing species' distributions along an environmental gradient using canonical analysis and quantile regression splines. Journal of Experimental Marine Biology and Ecology, 366, 1-2, 16-27. DOI: https://doi.org/10.1016/j. jembe.2008.07.006

AVIZ, D., CARVALHO, I. L. R. \& ROSA FILHO, J. S. 2012. Spatial and temporal changes in macrobenthic communities in the Amazon coastal zone (Guajará Estuary, Brazil) caused by discharge of urban effluents. Scientia Marina, 76, 2, 381-390. DOI: https://doi.org/10.3989/scimar.03312.16C

BARREIROS, J. P., BRANCO, J. O., FREITAS JÚNIOR, F., MACHADO, L., HOSTIM-SILVA, M. \& VERANI, J. R. 2009. Space-time distribution of the ichthyofauna from Saco da Fazenda Estuary, Itajaí, Santa Catarina, Brazil. Journal of Coastal Research, 255, 1114-1121. DOI: https://doi.org/10.2112/08-1050.1

BEMVENUTI, C. E. 1987. Predation effects on a benthic community in estuarine soft sediments. Atlântica, 9, 1, 5-32.

BEMVENUTI, C. E., CAPITOLI, R. R. \& GIANUCA, N. M. 1978. Estudos de ecologia bentônica na região estuarial da Lagoa dos 
Patos. Il. Distribuição quantitativa do macrobentos infralitoral. Atlântica, 3, 23-32.

BEMVENUTI, C. E., CATTANEO, S. \& NETTO, S. A. 1992. Características estruturais da macrofauna bentônica em dois pontos da região estuarial da Lagoa dos Patos, RS, Brasil. Atlântica, 14, 5-28.

BERNARDINO, A. F., PAGLIOSA, P. R., CHRISTOFOLETTI, R. A., BARROS, F., NETTO, S. A., MUNIZ, P. \& LANA, P. C. 2016. Benthic estuarine communities in Brazil: moving forward to long term studies to assess climate change impacts. Brazilian Journal of Oceanography, 64, 81-96. DOI: https://doi. org/10.1590/S1679-875920160849064sp2

BRAGA, C. F., MONTEIRO, V. F., ROSA-FILHO, J. S. \& BEASLEY, C. R. 2011. Benthic macroinfaunal assemblages associated with Amazonian saltmarshes. Wetlands Ecology and Management, 19, 257-272. DOI: https://doi.org/10.1007/s11273011-9215-5

CAPITOLI, R. R., BEMVENUTI, C. E. \& GIANUCA, N. M. 1978. Estudos de ecologia bentônica na região estuarial da Lagoa dos Patos. I-As comunidades bentônicas. Atlântica, 3, 5-22.

CAPOBIANCO, J. P. R., VERÍSSIMO, A., MOREIRA, A., SAWYER, D., SANTOS, I. \& PINTO, L. P. 2001. Biodiversidade na Amazônia brasileira: avaliação e ações prioritárias para a conservação, uso sustentável e repartição de benefícios, São Paulo, Instituto Socioambiental.

CARVALHO, S., PEREIRA, P., PEREIRA, F., DE PABLO, H., VALE C. \& GASPAR, M. B. 2011. Factors structuring temporal and spatial dynamics of macrobenthic communities in a eutrophic coastal lagoon (Óbidos lagoon, Portugal). Marine Environmental Research, 71, 2, 97-110. DOI: https://doi. org/10.1016/j.marenvres.2010.11.005

CARVALHO-NETA, R. N. F. \& CASTRO, A. C. L. 2008. Diversidade das Assembleias de Peixes Estuarinos da Ilha dos Caranguejos, Maranhão. Arquivos de Ciências do Mar, 41, 1, 48-57.

CHEVERIE, A. V., HAMILTON, D. J., COFFIN, M. R. S. \& BARBEAU, M. A. 2014. Effects of shorebird predation and snail abundance on an intertidal mudflat community. Journal of Sea Research, 92, 102-114. DOI: https://doi.org/10.1016/j.seares.2014.03.011

CLARKE, K. R. \& WARWICK, R. M. 1994. Change in marine communities: an approach to statistical analysis and interpretation. Plymouth, Plymouth Marine Laboratory, $144 \mathrm{p}$.

CONDIE, S. A., HAYES, D., FULTON, E. A. \& SAVINA, M. 2012. Modelling ecological change over half a century in a subtropical estuary: impacts of climate change, land-use, urbanization and freshwater extraction. Marine Ecology Progress Series, 457, 43-66. DOI: https://doi.org/10.3354/meps09718

DAJOZ, R. 1973. Ecologia geral, São Paulo, Vozes.

DAUER, D. M., LLANSÓ, R. J. \& LANE, M. F. 2008. Depth-related patterns in benthic community condition along an estuarine gradient in Chesapeake Bay, USA. Ecological Indicators, 8, 4, 417-424. DOI: https://doi.org/10.1016/j. ecolind.2007.02.009

DAY JUNIOR, J. W., CRUMP, B. C., KEMP, W. M. \& YÁÑES-ARANCIBIA, A. 2013. Estuarine Ecology, New York, John Wiley and Sons.

DEL-PILAR-RUSSO, Y., DE-LA-OSSA-CARRETERO, J. A., GIMÉNEZ-CASALDUERO, F. \& SÁNCHEZ-LIZASO, J. L. 2008. Effects of a brine discharge over soft bottom Polychaeta assemblage. Environmental Pollution, 156, 2, 240-250. DOI: https://doi. org/10.1016/j.envpol.2007.12.041
DITTMAN, S. 2002. Benthic fauna in tropical tidal flats - a comparative perspective. Wetlands Ecology and Management, 10, 189-195. DOI: https://doi.org/10.1023/A:1020119512225

EGRES, A. G., MARTINS, C. C., OLIVEIRA, V. M. \& LANA, P. C. 2012. Effects of an experimental in situ diesel oil spill on the benthic community of unvegetated tidal flats in a subtropical estuary (Paranaguá Bay, Brazil). Marine Pollution Bulletin, 64, 12, 2681-2691. DOI: https://doi.org/10.1016/j.marpolbul.2012.10.007

ELLIOTT, M. \& WHITFIELD, A. K. 2011. Challenging paradigms in estuarine ecology and management. Estuarine, Coastal and Shelf Science, 94, 4, 306-314. DOI: https://doi.org/10.1016/j. ecss.2011.06.016

FAO (Food and Agriculture Organization of the United Nations). 2007. The World's Mangroves 1980-2005. Rome: FAO Forestry Paper.

FEMAR (Fundação de Estudos do Mar). 1996. Costa brasileira: avaliação crítica e levantamento bibliográfico (1856-1996). Rio de Janeiro: FEMAR.

FERRANDO, A. \& MENDEZ, N. 2011. Effects of organic pollution in the distribution of annelid communities in the Estero de Urías coastal lagoon, Mexico. Scientia Marina, 75, 2, 351358. DOI: https://doi.org/10.3989/scimar.2011.75n2351

FERREIRA, A. C. \& LACERDA, L. D. 2016. Degradation and conservation of Brazilian mangroves, status and perspectives. Ocean \& Coastal Management, 125, 38-46. DOI: https://doi. org/10.1016/j.ocecoaman.2016.03.011

FREITAS JÚNIOR, F., CHRISTOFFERSEN, M. L., ARAÚJO, J. P. \& BRANCO, J. O. 2013. Spatiotemporal distribution and population structure of Monokalliapseudes schubarti (Tanaidacea: Kalliapseudidae) in an estuary in Southern Brazil. The Scientific World Journal, 2013, 363187. DOI: https://doi. org/10.1155/2013/363187

GAUDETTE H. E., FLIGHT W. R., TONER L. \& FOLGER D. W. 1974. An inexpensive titration method for the determination of organic carbon in recent sediments. Journal Sedimentary Petrology, 44, 249-253. DOI: https://doi.org/10.1306/74D729D72B21-11D7-8648000102C1865D

GIRI, C., OCHIENG, E., TIESZEN, L. L., ZHU, Z., SINGH, A., LOVELAND, T., MASEK, J. \& DUKE, N. 2011. Status and distribution of mangrove forests of the world using earth observation satellite data. Global Ecology and Biogeography, 20, 1, 154159. DOI: https://doi.org/10.1111/j.1466-8238.2010.00584.x

HAMILTON, D. J., DIAMOND, A. W. \& WELLS, P. G. 2006. Shorebirds, snails, and the amphipod (Corophium volutator) in the upper Bay of Fundy: top-down vs. bottom-up factors, and the influence of compensatory interactions on mudflat ecology. Hydrobiologia, 567, 285-306. DOI: https://doi. org/10.1007/s10750-006-0062-y

HAMMER, Ø. 2016. Paleontological Statistics: Reference manual, Version 3.14., viewed 05 January 2018, <http://folk.uio.no/ ohammer/past/past3manual.pdf> .

INMET (Instituto Nacional de Meteorologia). 2017. Banco de Dados Meteorológicos para Ensino e Pesquisa (BDMEP), viewed 20 December 2017, <http://www.inmet.gov.br/portal/index.php? $r=$ bdmep/bdmep $>$.

JACKSON, D. A. 1993. Stopping rules in principal components analysis: a comparison of heuristical and statistical approaches. Ecology, 74, 2204-2214. 
JOURDE, J., DUPUY, C., NGUYEN, H., MIZRAHI, D., PRACONTAL, N. \& BOCHER, P. 2017. Low benthic macrofauna diversity in dynamic, tropical tidal mudflats: migrating banks on Guiana's Coast, South America. Estuaries and Coasts.

JUMARS, P. A., DORGAN, K. M. \& LINDSAY, S. M. 2015. Diet of worms emended: an update of polychaete feeding guilds. Annual Review of Marine Science, 7, 497-520. DOI: https:// doi.org/10.1146/annurev-marine-010814-020007

KENNISH, M. J. 1997. Practical handbook of estuarine and marine pollution, Florida, CRC Press LLC.

KIMMERER, W. J. 2002. Physical, biological, and management responses to variable freshwater flow into the San Francisco estuary. Estuaries, 25, 1275-1290. DOI: https://doi. org/10.1007/BF02692224

LANA, P. C., ALMEIDA, M. V. O., FREITAS, C. A. F., COUTO, E. C. G., CONTI, L. M. P., GONZÁLEZ-PERONTI, A. L., GILES, A. G., LOPEZ, M. J. S., SILVA, M. H. C. \& PEDROSO, L. A. 1989. Estrutura espacial de associações macrobênticas sublitorais da Gamboa Perequê (Pontal do Sul, Paraná). Nerítica, 4, 1-2, 119-136.

LANA, P. C., CAMARGO, M. G., BROGIM, R. A. \& ISAAC, V. J. 1996. Os bentos da costa brasileira: avaliação crítica e levantamento bibliográfico (1858-1996). Rio de Janeiro, FEMAR.

LEITE, F. P. P. 1995. Distribuição temporal e espacial de Kalliapseudes schubarti Mañé-Garzón, 1949 (Crustacea, Tanaidacea) na região do Araçá, São Sebastião (SP). Arquivos de Biologia e Tecnologia, 38, 2, 605-618.

LEITE, F. P. P., TURRA, A. \& SOUZA, E. C. F. 2003. Population biology and distribution of the tanaid Kalliapseudes schubarti Mañe-Garzón, 1949, in an intertidal flat in Southeastern Brazil. Brazilian Journal of Biology, 63, 3, 469-479. DOI: https://doi.org/10.1590/S1519-69842003000300013

LUCERO, R. C. H., CANTERA, J. R. K. \& ROMERO, I. C. 2006. Variability of macrobenthic assemblages under abnormal climatic conditions in a small scale tropical estuary. Estuarine, Coastal and Shelf Science, 68, 1-2, 17-26. DOI: https://doi. org/10.1016/j.ecss.2005.11.037

MACKIE, A. S. Y. \& OLIVER, P. G. 1996. Marine macrofauna: Polychaetes, molluscs and crustaceans. In: HALL, G. S. (ed.) Methods for the examination of organismal diversity in soils and sediments. Wallingford: CAB International.

MARTINS, I. R., VILLWOCK, J. A., MARTINS, L. R. \& BEMVENUTI, C. E. 1989. The Lagoa dos Patos estuarine ecosystem (RS, Brazil). Pesquisas, 22, 5-44.

MENGE, B. A. 1995. Indirect effects in marine rocky intertidal interaction webs: patterns and importance. Ecological Monographs, 65, 1, 21-74. DOI: https://doi.org/10.2307/2937158

MOCHEL, F. R. 2011. Manguezais amazônicos: status para a conservação e a sustentabilidade na zona costeira maranhense. In: MARTINS, M. B. \& OLIVEIRA, T. G. (eds.) Amazônia maranhense: diversidade e conservação. Belém: Museu Paraense Emílio Goeldi.

MOCHEL, F. R., CORREIA, M. M. F., CUTRIM, M. V. J., IBAÑEZ, M. S. R., AZEVEDO, A. C. G., OLIVEIRA, V. M., PESSOA, C. R. D., MAIA, D. C., SILVEIRA, P. C., IBAÑEZ-ROJAS, M. O. A., PACHECO, C. M., COSTA, C. F. M., SILVA, L. M. \& PUISECK, A. M. B. 2001. Degradação dos Manguezais na llha de São Luís (MA): processos naturais e impactos antrópicos. In: PROST, M. T. \&
MENDES, A. C. (eds.) Ecossistemas Costeiros: Impactos e Gestão Ambiental. Belém: Museu Paraense Emílio Goeldi.

MONTAGNA, P. A. \& KALKE, R. D. 1992. The effect of freshwater inflow on meiofaunal and macrofaunal populations in the Guadalupe and Nueces Estuaries, Texas. Estuaries, 15, 307326. DOI: https://doi.org/10.2307/1352779

MONTAGNA, P. A. \& YOON, W. B. 1991. The effect of freshwater inflow on meiofaunal consumption of sediment bacteria in microphytobenthos in San Antonio Bay, Texas, U.S.A. Estuarine, Coastal and Shelf Science, 33, 6, 529-547. DOI: https:// doi.org/10.1016/0272-7714(91)90039-E

MONTEIRO NETO, C. \& MENDONÇA NETO, J. P. 2009. Biologia da conservação marinha. In: PEREIRA, R. C. \& GOMES, A. S. (orgs.) Biologia marinha. Rio de Janeiro: Interciência.

NANAMI, A., SAITO, H., AKITA, H., MOTOMATSU, K. \& KUWAHARA, H. 2005. Spatial distribution and assemblage structure of macrobenthic invertebrates in a brackish variables. Estuarine, Coastal and Shelf Science, 63, 1-2, 167-176. DOI: https://doi.org/10.1016/j.ecss.2004.11.004

NEWELL, R. C., SEIDERER, L. J. \& ROBINSON, J. E. 2001. Animal: sediment relationships in coastal deposits of the eastern English Channel. Journal of the Marine Biological Association of the United Kingdom, 81, 1, 1-9. DOI: https://doi.org/10.1017/ S0025315401003344

NGUYEN, H. T., DUPUY, C., JOURDE, J., LEFRANÇOIS, C., PASCAL, P. Y., CARPENTIER, A., CHEVALIER, J. \& BOCHER, P. 2018. Persistent benthic communities in the extreme dynamic intertidal mudflats of the Amazonian coast: an overview of the Tanaidacea (Crustacea, Peracarida). Marine Biodiversity, 48, 1841-1853. DOI: https://doi.org/10.1007/s12526-017-0679-2

OLIVEIRA, V. M. \& MOCHEL, F. R. 1999. Macroendofauna bêntica de substratos móveis de um manguezal sob impacto das atividades humanas no Sudoeste da ilha de São Luís, Maranhão, Brasil. Boletim do Laboratório de Hidrobiologia, 12, 75-93.

OURIVES, T. M., RIZZO, A. E. \& BOEHS, G. 2011. Composition and spatial distribution of the benthic macrofauna in the Cachoeira River estuary, Ilhéus, Bahia, Brazil. Revista de Biología Marina y Oceanografía, 46, 1, 17-25. DOI: https://doi. org/10.4067/S0718-19572011000100003

PAGLIOSA, P. R. \& BARBOSA, F. A. R. 2006. Assessing the environment-benthic fauna coupling in protected and urban areas of southern Brazil. Biological Conservation, 129, 3, 408-417. DOI: https://doi.org/10.1016/j.biocon.2005.11.008

POTTER, I. C., CHUWEN, B. M., HOEKSEMA, S. D. \& ELLIOTT, M. 2010. The concept of an estuary: a definition that incorporates systems which can become closed to the ocean and hypersaline. Estuarine, Coastal and Shelf Science, 87, 3, 497500. DOI: https://doi.org/10.1016/j.ecss.2010.01.021

RIBEIRO, R. P. \& ALMEIDA, Z. S. 2014. Anelídeos poliquetas do estado do Maranhão, Brasil: síntese do conhecimento. Bioikos, 28, 1, 45-55.

RODRIGUES, C. A. L., RIBEIRO, R. P., SANTOS, N. B. \& ALMEIDA, Z. S. 2016. Patterns of mollusc distribution in mangroves from the São Marcos Bay, coast of Maranhão State, Brazil. Acta Amazonica, 46, 4, 391-400. DOI: https://doi. org/10.1590/1809-4392201600493 
ROSA, L. C. \& BEMVENUTI, C. E. 2006. Temporal variability of the estuarine macrofauna of the Patos Lagoon, Brazil. Revista de Biología Marina y Oceanografía, 41, 1, 1-9. DOI: https://doi. org/10.4067/S0718-19572006000100003

SILVA, R. F., ROSA FILHO, J. S., SOUZA, S. R. \& SOUZA FILHO, P. W. 2011. Spatial and temporal changes in the structure of softbottom benthic communities in an Amazon estuary, Caeté estuary, Pará, Brazil. Journal of Coastal Research, SI 64, 440-444.

SILVA, A. F., FRANKLIN JÚNIOR, W. \& ROCHA-BARREIRA, C. A. 2017. Variação em pequena escala da macrofauna bentônica em uma planície de maré do estuário do rio Pacoti-Ceará, Brasil. Arquivos Ciências do Mar, 50, 107-123.

SNELGROVE, P. V. R. \& BUTMAN, C. A. 1994. Animal-sediment relationships revisited: cause versus effect. Oceanography and Marine Biology: Annual Review, 32, 111-177.

SOUSA, D. B., SANTOS, N. B., OLIVEIRA, V. M., CARVALHO-NETA, R. N. F. \& ALMEIDA, Z. S. 2015. Carcinofauna bêntica estuarina de dois manguezais da costa amazônica maranhense, Brasil. Iheringia, Série Zoologia, 105, 3, 339-347. DOI: https:// doi.org/10.1590/1678-476620151053339347
STRIDE, R. K. 1992. Diagnóstico da pesca artesanal marinha do Estado do Maranhão, São Luís, CORSUP/EDUFMA.

SUGUIO, K. 1973. Introdução à sedimentologia, São Paulo, Edgard Blücher Ltda./EDUSP.

THURMAN, C., HANNA, J. \& BENNETT, C. 2010. Ecophenotypic physiology: osmoregulation by fiddler crabs (Uca spp.) from the northern Caribbean in relation to ecological distribution. Marine and Freshwater Behaviour and Physiology, 43, 5, 339-356. DOI: https://doi.org/10.1080/10236244.2010.526407

WHITLATCH, R. B. 1981. Animal-sediment relationships in intertidal marine benthic habitats: some determinants of deposit-feeding species diversity. Journal of Experimental Marine Biology and Ecology, 53, 1, 31-45. DOI: https://doi. org/10.1016/0022-0981(81)90082-4

ZAR, J. H. 2010. Biostatistical analysis, New Jersey, Pearson Prentice-Hall. 